\title{
Urachal sinus leading to pyourachus presenting as recurrent periumbilical sepsis in an infant
}

\author{
Ken-win To, ${ }^{1,2}$ Leena Naidu, ${ }^{3}$ Harshawardhan Bilolikar ${ }^{2}$
}

'Department of Radiology, Nottingham University Hospitals NHS Trust, Nottingham, UK ${ }^{2}$ Department of Paediatrics, Kettering General Hospital NHS Foundation Trust, Kettering, UK ${ }^{3}$ Radiology, Kettering General Hospital, Kettering, UK

\section{Correspondence to} Dr Ken-win To, ken-win.to@nhs.net

Accepted 29 October 2017
CrossMark

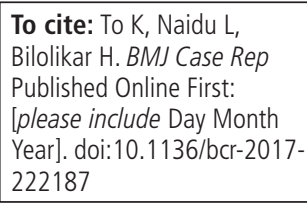

\section{DESCRIPTION}

A 5-month-old female infant presented with an 8 days duration of fever and irritability. In the previous 48 hours, she developed a rash around her umbilicus with reduced feeding and wet nappies (figure 1 ). She was born at $38+3 / 40$ weeks gestation by caesarean section for breech presentation. At 4 months of age, she had gastro-oesophageal reflux. She initially presented to the general practitioner (GP) at 3 months of age with redness around the umbilicus and dried clots in the centre without any swelling. She had no fever and was otherwise well. Initial treatment given by GP included a 1-week course of oral flucloxacillin for provisional diagnosis of infected umbilical granuloma. This seemed to have resolved her symptoms.

The baby was referred for paediatric assessment by her GP with recurrent symptoms mentioned above. On examination, periumbilical erythema was present with no obvious tenderness. A diffuse superficial swelling with induration was noted to the left side of the umbilicus. This had enlarged over a few hours rapidly, measuring $3 \times 3 \mathrm{~cm}$ from twice its original size.

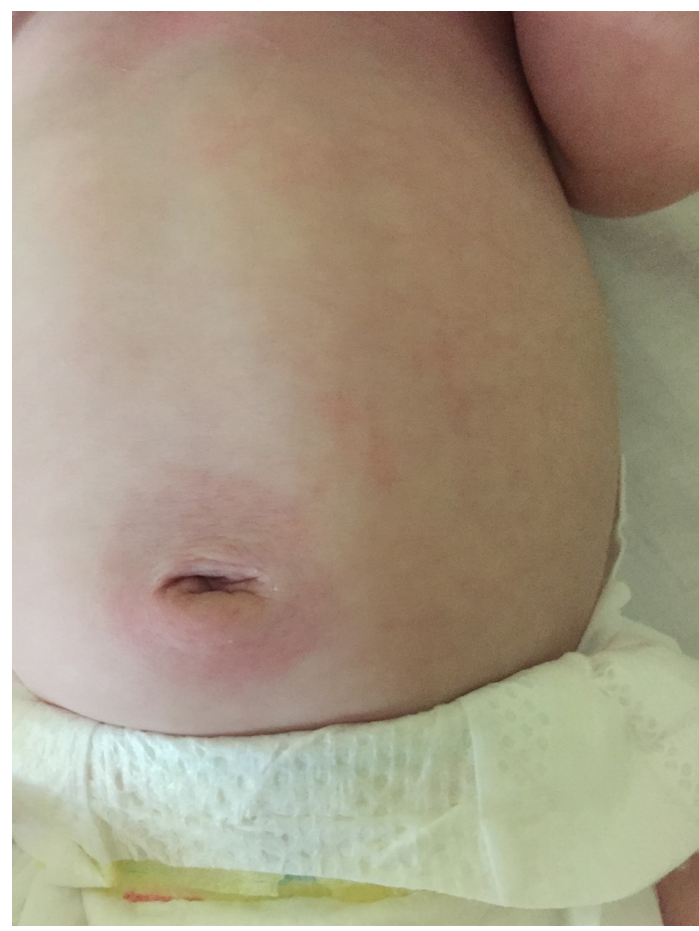

Figure 1 Clinical photograph showing a diffuse periumbilical erythema.

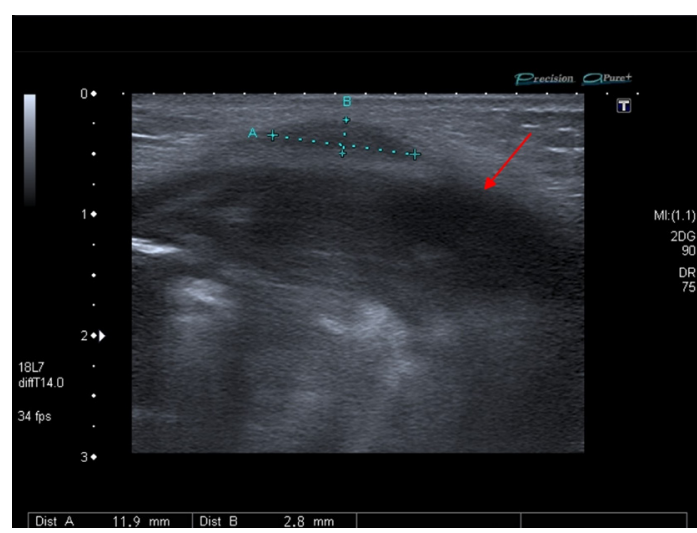

Figure 2 Ultrasound abdomen of the periumbilical region. The red arrow showing a complex mass just to the left of the midline.

Blood results showed a raised C-reactive protein of $72 \mathrm{mg} / \mathrm{dL}$ and platelets $719 \times 10^{9} / \mathrm{L}$. White cell count of $32.3 \times 10^{9} / \mathrm{L}$ and neutrophils $15.9 \times 1000 /$ $\mathrm{mm}^{3}$ were also raised consistent with infection.

She was started on intravenous flucloxacillin. A clinical diagnosis of urachal sinus leading to infection of the urachal cyst or embryonic remnants of vitellointestinal tract was considered and an ultrasound requested. Ultrasound showed a sinus tract leading to an infected cyst (figure 2). The CT abdomen was performed to delineate the anatomy further and it confirmed the presence of an urachal sinus leading to an infected and complex urachal cyst measuring $5.6 \times 2.8 \times 4.2 \mathrm{~cm}$ (figure 3). Intravenous flucloxacillin resolved the umbilical redness and the underlying infection.

No visible swelling or abscess was observed after 4 days. She was discharged home with paediatric urology follow-up for possible further surgery and excision of the cyst.

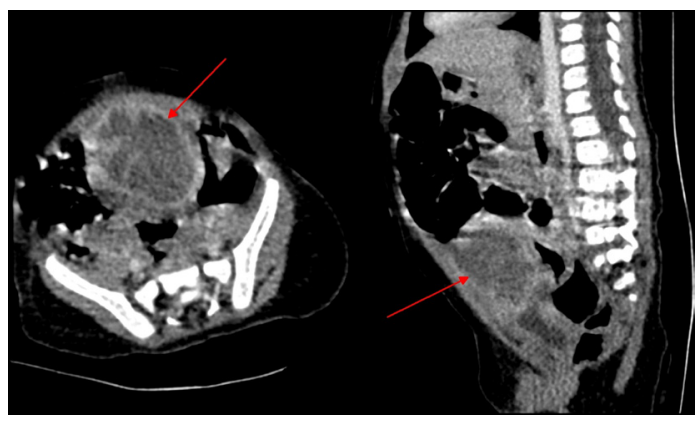

Figure 3 Abdominal CT showing a multicystic mass extending from urinary bladder inferiorly to the level of the umbilicus (red arrow). 
Urachal sinus and cysts are rare. They arise from incomplete regression of the fetal urachus between the umbilicus and bladder. They are usually silent clinically until infection, calculi or cysts develop. ${ }^{1}$ In rare occasions, they can present late into adulthood as an infection. ${ }^{23}$ Rare cases of adenocarcinoma have been described. Due to their non-specific presentation, diagnosis can be missed if not actively considered. ${ }^{4}$ A similar case

\section{Learning points}

Urachal sinus and cysts are rare and can present as recurring periumbilical sepsis.

- A non-resolving umbilical granuloma or rapidly expanding umbilical or periumbilical mass should alert the clinician to possibility of this condition.

- If missed for a number of years, a potential for malignant change exists. with prolapsed urachal sinus leading to the pyourachus has been reported recently. ${ }^{5}$

Contributors KWT was involved in the case, reviewed the case notes and wrote the article. LN helped to identify and annotate the radiological images. HB was the overseeing consultant.

Competing interests None declared.

Patient consent Obtained.

Provenance and peer review Not commissioned; externally peer reviewed.

(c) BMJ Publishing Group Ltd (unless otherwise stated in the text of the article) 2017. All rights reserved. No commercial use is permitted unless otherwise expressly granted.

\section{REFERENCES}

1. Patel RV. Umbilical anomalies and disorders. Surgery 1999;4:21-5.

2. Bannon A, Black P, Turner J, et al. Belly button piercings: a saving grace? A patent urachus presenting in a 17-year-old girl. BMJ Case Rep 2014;2014.

3. Gami BL, Biswas S. An infected urachal cyst. BMJ Case Rep 2013:2013.

4. Yu JS, Kim KW, Lee HJ, et al. Urachal remnant diseases: spectrum of $\mathrm{CT}$ and US findings. Radiographics 2001;21:451-61.

5. Lane V, Patel R, Daniel RD. Prolapsed urachal sinus with pyourachus in an infant. J Pediatr Surg 2013;48:e17-19.

Copyright 2017 BMJ Publishing Group. All rights reserved. For permission to reuse any of this content visit http://group.bmj.com/group/rights-licensing/permissions.

BMJ Case Report Fellows may re-use this article for personal use and teaching without any further permission.

Become a Fellow of BMJ Case Reports today and you can:

- Submit as many cases as you like

- Enjoy fast sympathetic peer review and rapid publication of accepted articles

- Access all the published articles

Re-use any of the published material for personal use and teaching without further permission

For information on Institutional Fellowships contact consortiasales@bmjgroup.com

Visit casereports.bmj.com for more articles like this and to become a Fellow 